\title{
The Metabolism of Ketones, Triglyceride and Monoglyceride in Livers of Obese Hyperglycaemic Mice
}

\author{
J.M. STEen, P.D. Bewsher and J.M. STowers
}

Department of Therapeutics and Pharmacology, University of Aberdeen, Aberdeen, Great Britain

Received: March 28, 1970

Summary. Some aspects of fat metabolism and ketogenesis have been investigated in obese hyperglycaemic mice, their non-obese littermates and normal mice. The proportion of total liver lipids was greatest in the obese mice, and the fatty acid composition of the liver total lipids showed a greatly reduced proportion of linoleic acid in the obese mice when compared with the other groups. Whole liver homogenates showed low rates of lipolysis of endogenous fat, but defatted liver homogenates showed a rapid lipolysis of added monoglyceride. Free fatty acid levels in the livers of obese mice were lower than in littermates or in normal mice. Total ketone production by liver slices from obese mice was lower than from nor. mal mice. It was concluded that ketone production by the obese mice was related to liver free fatty acid levels rather than to total liver lipid.

Métabolisme des corps cétoniques, des triglycérides et des monoglycérides dans le foie de souris obèses hyperglycémiques

Résumé. Certains des aspects du métabolisme des graisses et de la cétogenèse ont été examinés chez des souris hyperglycémiques obèses, leurs compagnons de portée non-obèses et chez des souris normales. La proportion des lipides totaux du foie s'est révélée comme étant la plus grande chez les souris obèses, et la composition d'acide gras des lipides totaux du foie a fait apparaître chez les souris obèses une proportion d'acide linoléique qui était largement réduite par rapport aux autres groupes. Des homogénats de foie complet ont montré des taux de lipolyse de graisse endogène peu élevés, mais des homogénats de foie dégraissé ont montré une lipolyse rapide de monoglycéride ajoutée. Les taux d'acide gras libre dans les foies des souris obèses étaient plus bas que ceux de leurs compagnons de partée ou des souris normales. La production cétonique totale des tranches de foie provenant des souris obèses était moins élevée que celle des souris normales. II en a été conclu que la production de corps cétoniques chez les souris obèses était liée aux taux d'acide gras libre du foie plutôt qu'aux lipides du foie total.

Der Stoffwechsel der Ketonkörper, der Triglyceride und der Monoglyceride in der Leber von fetten hyperglykämischen Mäusen

Zusammenfassung. Einige Aspekte des Fettstoffwechsels und der Ketogenese wurden bei fetten hyperglykämischen Mäusen, ihren nichtfetten Wurfgeschwistern und normalen Mäusen untersucht. Der Anteil der Gesamtleberlipide war am größten bei den fetten Mäusen; die Fettsäurenzusammensetzung dor Lebergesamtlipide zeigte einen stark reduzierten Anteil der Linolsäure bei fetten Mäusen, wenn man sie mit den andern Gruppen verglich. Die Gesamtleber-Homogenate zeigten niedrige Quoten der Lipolyse endogenen Fettes, aber entfettete Leberhomogenate zeigten eine schnelle Lipolyse zugesetzter Monoglyceride. Der Spiegel der freien Fettsëuren in den Lebern fetter Mäuse war niedriger als bei den Wurfgeschwistern oder bei normalen Mäusen. Die Gesamtketonkörper-Produktion von Leberschnitten fetter Mäuse war niedriger als bei normalen Mäusen. Es wird der Schluß gezogen, daß die Ketonkörperproduktion fetter Mäuse eher auf das Niveau der freien Fettsäuren der Leber als auf die Gesamtleberlipide zu beziehon ist.

Key-words: Obese hyperglycaemic mice, liver lipids, fatty acids, linoleic acid, ketogenesis.
The Bar Harbor strain of genetically obese hyperglycaemic mice was first described in 1950 (Ingalls, Dickie and Snell) and since that time has been extensively investigated. Many physiological and biochemical differences have been described between the obese mice, (bearing the double recessive gene promoting obesity) and their non-obese littermates. So far no single factor corresponding to a genetic lesion promoting obesity has been conclusively demonstrated. Rather, the obese mice appear to possess a complex of changed metabolic characteristics, some of which may have contributed to the obese state, and some possibly have resulted from it.

The incorporation of carbon atoms from glucose, lactate and glycerol into fatty acids in the livers of obese mice is significantly greater than in the lean littermates (Shreeve, Lamdin, Oji and Slavinski, 1967). Increased activity of citrate cleavage enzyme has been demonstrated (Kornacker and Lowenstein, 1964) and also increased activities of malic dehydrogenase, lactic dehydrogenase and $\alpha$-glycerophosphate dehydrogenase (Fried and Antopol, 1966). The conversion of ${ }^{14} \mathrm{C}$ from glucose into liver cholesterol was found to be similar in the obese and non-obese mice, but nevertheless there was a considerable accumulation of cholesterol in the livers of the obese mice after twelve weeks (Jansen, Zanetti and Hutchison, 1967).

In the fasting state, the obese mice are mildly hyperglycaemic, and their plasma insulin levels are higher than those of the non-obese littermates (Stauffacher, Lambert, Vecchio and Renold, 1967). Plasma ketone levels in the obese mice are similar to those in normal mice, but on fasting, a slight drop in plasma ketone levels has been observed in obese mice in contrast to the rise produced by fasting in normal mice (Mayer and Silides, 1958). Mobilization of free fatty acids (FFA) in response to adrenaline and to fasting is impaired (Marshall and Engel, 1960); even after 
prolonged fasting there appears to be no increase in FFA content of the adipose tissue of the obese mice (Hollifield, Perlman and Parson, 1962). The obese mice, during their normal life span, show no signs of ketosis or weight loss, despite their hyperglycaemia.

Our object was to study the rate of breakdown of triglyceride and monoglyceride in the livers of obese mice and their non-obese littermates, and to see whether this could be correlated with ketone production by liver slices.

\section{Methods}

A colony of obese hyperglycaemic mice (strain C57BL/6Job) was bred in Aberdeen from an initial stock of four breeding pairs obtained from Jackson Laboratories, Bar Harbor, Maine, U.S.A. All the mice were fed Mouse Cake Diet F.F.G. ${ }^{1}$ and were aged 5 to 8 months during these studies. Three groups of mice were investigated. The first group consisted of obese mice weighing between $40-60 \mathrm{~g}$ and the second group were non-obese littermates with weights between $24-36 \mathrm{~g}$. The third group was a related strain of normal mice $(\mathrm{C} 57 \mathrm{BL})^{2}$ weighing $22-32 \mathrm{~g}$. On any single experimental day mice of the same age and sex were used. No differences that could be attributed to sex were found and accordingly the final figures contain results from males and females. The mice were starved for $24 \mathrm{~h}$ before being killed by a sharp blow on the head.

Total fat was extracted from the mouse livers by the method of Bligh and Dyer (1959). The chloroform extracts were dried over $\mathrm{Na}_{2} \mathrm{SO}_{4}$ and evaporated to constant weight in a water bath in an atmosphere of nitrogen. Butylated hydroxytoluene was added to the solvents as an antioxidant.

Protein content of the liver homogenates was estimated by the method of Lowry et al. (1951), using bovine albumin (Armour fraction V) as standard.

The analysis of total fatty acids of the liver was carried out using a Pye argon gas chromatograph. The lipid extracts were methylated by a modification of the method of Morrison and Smith (1964), and the methyl esters separated on a column of polyethylene glycol adipate, (temp. $185^{\circ} \mathrm{C}$ ). The peaks were identified by comparison with retention times of known standards, and peak areas were estimated by triangulation.

Liver lipase activity (Bewsher and Ashmore, 1966) was measured using $10 \%$ homogenates of liver in Ringer-bicarbonate buffer ( $\mathrm{pH}$ 7.4) (Spiro, Ashmore and Hastings, 1958) and incubating at $37^{\circ} \mathrm{C}$ for $30 \mathrm{~min}$. Initial and final FFA values were estimated using the method of Dole (1956) as modified by Mosinger (1965).

Liver monoglyceride lipase activity was measured by a modification of the method used for adipose

1 Supplied by E. Dixon \& Sons (Ware) Ltd., Crane Mead Mills, Ware, Herts..

2 Supplied by Moredun Institute, Gilmerton, Edinburgh. tissue (Strand, Vaughan and Steinberg, 1964). A 5\% homogenate of liver was prepared in $0.1 \mathrm{M}$ phosphate buffer at $\mathrm{pH}$ 7.5. The incubation was carried out at $37^{\circ} \mathrm{C}$. for $30 \mathrm{~min}$. The reaction mixture contained $2.5 \mathrm{mg}$ liver, $4 \mathrm{mg}$ monopalmitin (Sigma Co.), $40 \mathrm{mg}$ bovine serum albumin (Armour fraction $\nabla$ ) and 0.1 mmoles phosphate buffer, in a final volume of $1 \mathrm{ml}$. The stock monopalmitin emulsion was prepared in a glass homogeniser, with $10 \mathrm{mg}$ monopalmitin $/ \mathrm{ml}$. Addition of this emulsion to the reaction mixture invariably produced precipitation of the monopalmitin during the incubation. To prevent this, the emulsion was stabilized by adding sodium taurocholate (Sigma Co.) $(1.2 \mathrm{mg} / \mathrm{ml}$ final mixture). Fatty acid release was measured by the method of Duncombe (1963) as modified by Vaughan, Berger and Steinberg (1964), with appropriate controls for spontaneous release of FFA from monopalmitin, and for release of FFA from liver incubated without added substrate.

For studies on ketogenesis, liver slices were incubated at $37^{\circ} \mathrm{C}$ in Ringer-bicarbonate buffer ( $\mathrm{pH}$ 7.4) with $95 \% \mathrm{O}_{2}$ and $5 \% \mathrm{CO}_{2}$ as the gas phase. Enzymic methods were used to estimate acetoacetate and $\beta$-hydroxybutyrate production (Williamson, Mellanby and Krebs, 1962).

\section{Results}

Table 1 shows that the level of free fatty acids (FFA) in livers of fasted obese mice was significantly lower than the level of FFA in fasted littermate or normal livers. However, total liver lipids, expressed as $\mathrm{mg} / \mathrm{g}$ wet weight liver, were found to be significantly greater in obese livers, than in normal or littermate livers. The average weight of the liver from an obese mouse was about three times that of a littermate or normal liver. Thus total fat stored in each obese liver was at least four times that of a littermate liver and six times that of a normal liver. There appeared to be no difference in protein content of obese and littermate livers expressed as $\mathrm{mg}$ protein/g liver.

The composition of the fatty acids of the liver lipids was determined (Table 2a). The most striking difference between the groups was that the proportion of linoleic acid $(\mathrm{C} 18: 2)$ in the obese liver lipids was only one-third of that of the normal livers. The proportion of linoleic acid in the littermates tended to resemble that in the normal livers. The reverse situation was noted with oleic acid (C18:1), a greater proportion of which was present in the obese livers than in the normal or littermate livers. The composition of the mouse diet is included, and it is interesting to note that lipid accounted for only $2 \%$ of the total weight of the diet indicating that the mice must synthesize fatty acids from dietary carbohydrates.

The data in Table 2 a has been recalculated (Table 2 b) to give the weight of each fatty $y_{*}^{*}$ acid in the whole livers of obese, littermate and normal mice. It can be seen that obese livers contained increased amounts of all fatty acids, compared with littermate and normal 
livers. The most marked increase was in oleic acid (C18:1) which was about ten times the weight of that in normal livers; and also palmitoleic acid (C16:1) and palmitic acid (C16) which were greatly increased above the amounts in normal livers. palmitin lipolysis rates of obese and littermate livers. A comparison of FFA production from liver lipid and from monopalmitin shows a notable difference between the activities of tri- and monoglyceride lipases in liver in vitro.

Table 1. Free fatty acid, protein, and total lipid content of obese, littermate and normal mouse livers, after $24 h$ fasting. The number of animals in each group is indicated in brackets. Mean values $\perp$ S.E.M.

\begin{tabular}{llllll}
\hline & Obese & Littermate & $\begin{array}{l}P \text { values (obese Normal } \\
\text { compared with } \\
\text { littermates) }\end{array}$ & $\begin{array}{l}P \text { value } \\
\text { (obese com- } \\
\text { pared with } \\
\text { normals) }\end{array}$ \\
\hline $\begin{array}{l}\text { Free fatty acids } \\
\text { ( } \mu \text { Eq/g liver) }\end{array}$ & $4.25 \pm 0.3(10)$ & $5.7 \pm 0.2(8)$ & $P<0.01$ & $6.8 \pm 0.2(6)$ & $P<0.001$ \\
$\begin{array}{l}\text { Total lipid } \\
\text { (mg/g liver) }\end{array}$ & $164 \pm 14(8)$ & $101 \pm 14(8)$ & $P<0.01$ & $89 \pm 10(6)$ & $P<0.01$ \\
$\begin{array}{l}\text { Protein } \\
\text { (mg protein/g }\end{array}$ & $117.9 \pm 14.6(4)$ & $128.2 \pm 4.0(5)$ & & & \\
$\begin{array}{l}\text { liver } \\
\text { Average weight } \\
\text { of whole liver in g }\end{array}$ & $4.9(6)$ & $1.6(6)$ & & $1.3(6)$ & \\
\hline
\end{tabular}

Table 2. Analysis by gas chromatography of fatty acids of total liver lipids of obese, littermate and normal mice

\begin{tabular}{|c|c|c|c|c|c|c|c|}
\hline \multicolumn{8}{|c|}{ (a) Percentage Composition of Main Fatty Acid Components } \\
\hline Fatty Acid & $14: 0$ & $16: 0$ & $16: 1$ & $18: 0$ & 18: 1 & $18: 2$ & $18: 3$ \\
\hline Obese $\quad(4)$ & 0.3 & 25.8 & 14.0 & 0.9 & 52.3 & 6.9 & Trace \\
\hline Littermate (4) & 0.3 & 33.0 & 15.1 & 1.7 & 34.8 & 15.8 & Trace \\
\hline Normal (4) & 0.2 & 32.8 & 11.7 & 3.0 & 31.8 & 20.6 & Trace \\
\hline Diet & 1.2 & 23.7 & 6.0 & 1.5 & 15.7 & 46.4 & 3.5 \\
\hline \multicolumn{8}{|c|}{ (b) Main fatty acid components expressed as mg/whole liver } \\
\hline Obese & 3 & 207 & 113 & 7 & 420 & 55 & \\
\hline Littermate & 1 & 53 & 24 & 3 & 56 & 42 & \\
\hline Normal & $<1$ & 38 & 14 & 4 & 37 & 24 & \\
\hline
\end{tabular}

Table 3. Lipolysis of endogenous lipid by liver homogenates, and of added monopalmitin by etherextracted liver homogenates, after $24 \mathrm{~h}$ fasting. The number of animals in each group is indicated in brackets. Mean values \pm S.E.M. Results expressed as $\mu E q F F A$ produced/g liver/hour

\begin{tabular}{|c|c|c|c|c|c|}
\hline & Obese & Littermates & $\begin{array}{l}P \text { value } \\
\text { (obese com- } \\
\text { pared with. } \\
\text { littermates) }\end{array}$ & Normals & $\begin{array}{l}P \text { value } \\
\text { (obese com- } \\
\text { pared with } \\
\text { normals) }\end{array}$ \\
\hline $\begin{array}{l}\text { Endogenous } \\
\text { liver lipid }\end{array}$ & $1.85 \pm 0.2(10)$ & $0.9 \pm 0.15(6)$ & $P<0.01$ & $1.1 \pm 0.2(6)$ & $P<0.05$ \\
\hline Monopalmitin & $850 \pm 44(5)$ & $770 \pm 50(7)$ & $*$ N.S. & & \\
\hline
\end{tabular}

* Not significant.

Homogenates of mouse livers were used to measure FFA production from endogenous liver lipid and from monopalmitin (Table 3). The rate of lipolysis from endogenous liver lipid was low in all three groups, but the rate in livers from obese mice, expressed as FFA produced/g liver. $h$, was greater than that in normal mice or in the littermates.

Monopalmitin, when added as an emulsion to defatted liver homogenates, was very rapidly hydrolyzed. There was no significant difference between the mono-
Since protein contents of the liver homogenates were similar (Table 1), lipase activity did not differ between the two groups whether expressed per gram of liver or per milligram liver protein.

Total ketone production by livers from obese mice was significantly lower than that by the normal controls $(P<0.01)$ (Table 4$)$. Littermates were intermediate in ketone production. The difference between obese and normal mice was most marked in acetoacetate production $(P<0.001)$. $\beta$-hydroxybutyrate fig- 
ures, although lower, followed the same trend. When total ketone production was expressed in terms of liver lipid content the differences between the groups of animals was accentuated. animals when compared with littermates and controls. In other words, the greater the liver lipid content, the lower the rate of ketone production. The rate of flow of FFA from the peripheral adipose tissues to the liver

Table 4. Ketone production by liver slices of obese, normal, and littermate mice after $24 \mathrm{~h}$ fasting ( $\mu$ moles $/ g .90 \mathrm{~min}$ ). The number of animals in each group is indicated by brackets. Mean values \pm S.E.M.

\begin{tabular}{lrrlrl}
\hline & Acetoacetate & $\begin{array}{l}\beta \text {-Hydroxybu- } \\
\text { tyrate }\end{array}$ & & \multicolumn{1}{l}{$\begin{array}{l}\text { Total ketones } \\
\text { mg lipid }\end{array}$} \\
\hline Obese & $(6)$ & $\mathbf{2 . 8 3} \pm \mathbf{0 . 4 7}$ & $1.25 \pm \mathbf{0 . 1 9}$ & $4.08 \pm 0.53$ & $0.026 \pm 0.003$ \\
Littermate (6) & $7.69 \pm \mathbf{1 . 9 0}$ & $1.96 \pm 0.60$ & $\mathbf{1 0 . 5 8 \pm 2 . 0 4}$ & $0.098 \pm 0.019$ \\
Normal & $(6)$ & $\mathbf{1 2 . 8 0 \pm 1 . 0 1}$ & $\mathbf{3 . 9 3} \pm \mathbf{0 . 4 8}$ & $\mathbf{1 7 . 2 4 \pm 1 . 1 8}$ & $0.196 \pm 0.013$ \\
\hline
\end{tabular}

\section{Discussion}

Our results showed greatly increased amounts of total liver lipid. The fatty acid composition of this lipid (Table 2), in which the proportion of oleic acid (which can be synthesized) was greatly increased, and the proportion of linoleic acid (which cannot be synthesized) was very markedly decreased, seems to be an indication that the increased fat of the livers of the obese mice was synthesized in situ. The fatty acid composition bore a strong resemblance to the fatty acid composition of the livers of mice fed a fat-free diet (Allman and Gibson, 1965). These authors noted that accumulation of triglyceride in the liver was evident early in the fat-deficient state, and that this accumulation could be prevented by the addition of linoleate to the diet.

The low rate of breakdown of triglyceride by liver homogenates was in agreement with the low values obtained from rat livers, using the same method (Bewsher and Ashmore, 1966). There are few references to a lipase in liver (Green and Webb, 1964). However, the lipolysis observed, though low, was consistent, and it was interesting to note that the highest rate of lipolysis, expressed per g liver, occurred in the obese livers, which had the lowest rate of ketone body formation. Since the rate of lipolysis of monoglyceride was many times faster than that of triglyceride, there can be no free monoglyceride in the liver during triglyceride breakdown. The monoglyceride lipolysis rates for obese and non-obese mice could not be related to ketogenesis.

The low rate of ketone production by liver slices from the starved obese mice is consistent with the failure of blood ketone levels to rise in starved obese mice, observed by Mayer and Silides (1958). Scow and Chernick (1960) have shown that ketone production in rats is closely correlated with the total lipid content of the liver, and have indicated that, expressed according to liver fat content, the rates of ketogenesis by livers from starved and diabetic animals are similar. The obese hyperglycaemic mice used in the experiments described above do not follow this general rule, and the rate of ketone production, when expressed per milligram of liver lipid, is even more reduced in the obese is one of the major factors regulating the rate of ketogenesis. Obese mice do not readily mobilize FFA in response to starvation (Marshall and Engel, 1960; Hollifield et al. 1962) and the liver FFA levels found in the experiments described here suggest that mobilisation of FFA from periphery to liver is reduced, and is not compensated by the significant increase in hydrolysis of liver triglyceride, which possibly plays only a small part in determining the rate of ketogenesis anyway. The results of these experiments indicate that ketogenesis in both the obese and the normal mice may be related to FFA levels within the liver rather than the total liver lipid content.

Acknowledgements: We should like to express our thanks to Dr. Tain Ross for the fatty acid analyses of the liver lipids, to Mr. I. Pittendreigh for valuable assistance throughout, and to Mrs. M. Bathgate for supervision of the breeding of the obese mice. We also thank Professor A. G. Macgregor for his interest and encouragement.

The work was supported by a grant from the British Diabetic Association and from the Scottish Hospitals Endowment Research Trust.

\section{References}

Allman, D.W., Gibson, D.M.: Fatty acid synthesis during early linoleic acid deficiency in the mouse. J. Lipid Res. 6, $51-62(1965)$.

Bewsher, P.D., Ashmore, J.: Ketogenic and lipolytic effects of glucagon on liver. Biochem. biophys. Res. Commun. 24, $431-436$ (1966).

Bligh, E.G., Dyer, W.J.: A rapid method of total lipid extraction and purification. Canad. J. Biochem. Physiol. 37, 911-917 (1959).

Dole, V.P.: A relation between non-esterified fatty acids in plasma and the metabolism of glucose. J. clin. Invest. $35,150-154(1956)$.

Duncombe, W.G.: The colorimetric micro-determination of long-chain fatty acids. Biochem. J. 88, 7-10 (1963).

Fried, G.H., Antopol, W.: Enzymatic activities in tissues of obese hyperglycemic mice. Amer. J. Physiol. 211, 1321-1324 (1966).

Green, C., Webb, J.A.: The uptake of chylomicron fatty acids by isolated liver cells. Biochem. biophys. Acta 84, 404-411 (1964).

Hollifield, G., Perlman, M., Parson, W. : Free acid content of adipose tissue in three types of obese mice during fasting. Metabolism 11, 117-122 (1962).

Ingalls, A.M., Dickie, M.M., Snell, G.D.: Obese, a now mutation in the house mouse. J. Hered. 41, 317-318 (1950). 
Jansen, G.R., Zanetti, M.E., Hutchison, C.F.: Studies of lipogenesis in vivo. Fatty acid and cholesterol synthesis in hyperglycaemic-obese mice. Biochem. J. 102, 870877 (1967).

Kornacker, M.S., Lowenstein, J.M.: Citrate cleavage enzyme in livers of obese and non-obese mice. Science N.Y. 144, 1027-1028 (1964).

Lowry, O.H., Rosebrough, N.J., Farr, A.L., Randall, R. J.: Protein measurement with the Folin phenol reagent. J. biol. Chem. 193, 265-275 (1951).

Marshall, N.B., Engel, F. L.: The influence of epinephrine and fasting on adipose tissue content and release of free fatty acids in obese hyperglycemic and lean mice. J. Lipid Res. 1, 339-342 (1960).

Mayer, J., Silides, D.J.: Fat metabolism in experimental obesitios VIII. Blood total lipids and ketones in four kinds of obese mice. Experientia 14, 96-98 (1958).

Morrison, W.R., Smith, L.M.: Preparation of fatty acid methyl esters and dimethylacetals from lipids with boron fluoride-methanol. J. Lipid Res. 5, 600-608 (1964).

Mosinger, F.: Photometric adaptation of Dole's microdetermination of free fatty acids. J. Lipid Res. 6, 157159 (1965).

Shreeve, W.W., Lamdin, E., Oji, N., Slavinski, R.: Biosynthesis of fatty acids in obese mice in vivo. 1 . Studies with glucose-1- ${ }^{3} \mathrm{H}\left(1-{ }^{14} \mathrm{C}\right)$, glucose- $6{ }^{3} \mathrm{H}\left(6-{ }^{14} \mathrm{C}\right)$, DLlactate-2. ${ }^{3} \mathrm{H}\left(2-{ }^{14} \mathrm{C}\right)$ and glycerol $-2{ }^{3} \mathrm{H}\left(1.3-{ }^{14} \mathrm{C}\right)$. Biochemistry, N.Y.6, 1160-1167 (1967).
Scow, R.O., Chernick, S.S.: Hormonal control of protein and fat metabolism in the pancreatectomised rat. Recent Progr. Hormone Res. 16, 497-541 (1960).

Spiro, R. G., Ashmore, J., Hastings, A.B.: Studies on carbohydrate metabolism in liver slices. J. biol. Chem 230, $761-771$ (1958).

Stauffacher, W., Lambert, A.E., Vecchio, D., Renold, A.E.: Measurements of insulin activities in pancreas and serum of mice with spontaneous ("obese" and "New Zealand" obese) and induced (gold thioglucose) obesity and hyperglycaemia, with considerations on the pathogenesis of the spontaneous syndrome. Diabetologia 3, $230-237$ (1967).

Strand, O., Vaughan, M., Steinberg, D. : Rat adipose tissue lipases : hormone-sensitive lipase activity against triglycerides compared with activity against lower glycerides. J. Lipid Res. 5, 554-562 (1964).

Vaughan, M., Berger, J.E., Steinberg, D.: Hormonesensitive lipase and monoglyceride lipase activities in adipose tissue. J. biol. Chem. 239, $401-409$ (1964).

Williamson, D.H., Mellanby, J., Krebs, H. A.: Enzymatic determination of $D(-)-\beta$-hydroxybutyric acid and acetoacetic acid in blood. Biochem. J. 82, 90-96 (1962).

\section{Dr. Janet Stein}

Dept. of Biochemistry

University of Cambridge

Tennis Court Road

Cambridge, Great Britain 